\title{
Carbon sequestration of above-ground biomass of Pinus sylvestris L. in the green belt of the city of Astana
}

\author{
Assel R. Tumenbayeva ${ }^{1}$, Dani N. Sarsekova ${ }^{1}$, Stanisław Małek ${ }^{2} \bowtie$ \\ ${ }^{1}$ S. Seifullin Kazakh Agro-Technical University, Faculty of Agronomy, Department of Forest Resources and Forestry, \\ Astana 010011, Kazakhstan \\ ${ }^{2}$ University of Agriculture in Krakow, Faculty of Forestry, Department of Forest Ecology and Reclamation, \\ al. 29 Listopada 46, 31-425 Kraków, Poland, e-mail: stanis.malek@gmail.com
}

\begin{abstract}
The article presents the results of research in the pine plantations located in the green belt of the city of Astana, the dry steppe zone of Northern Kazakhstan, and in the research, the data on biomass and carbon content in various fractions of Scots pine were obtained. Assessment of morphometric parameters of the pine stands was carried out by measuring tree height and trunk diameter at breast height (DBH); to determine the carbon content, laboratory analytical methods were used. Samples were taken from each element of biomass (branches, trunk, leaves, and bark) of Scots pine, in triplicate. After that, the green mass was weighed on the analytical scales to within $0.001 \mathrm{~g}$. The samples were then dried to a constant weight at a temperature of $65^{\circ} \mathrm{C}$. In laboratory samples without mineralization, the content of carbon was determined using element analyser. Regression equations were used to calculate the biomass of stocks. To measure the taxation indicators and sampling of plantations, trial plots were laid in triplicate for trial plots, the height of plantations varied on average from $5.8 \mathrm{~m}$ to $8.4 \mathrm{~m}$ on the plotted trial plots, and the diameter of the trunk varied from $7.7 \mathrm{~cm}$ to $8.8 \mathrm{~cm}$. The correlation between plant height and stem diameter was 0.745 . As the studies of chemical composition in needles, bark, trunk and branches of pine trees showed, the amount of carbon was from 50.03 to $51.33 \%$. Thus, the study of the chemical composition of the pine plantations showed that the greatest content of chemical elements, such as carbon, was in tree needles. The accumulation plantations of Pinus sylvestris $L$. in the green belt of the city of Astana were sequestrated 973.3 tons of carbon in the above-ground biomass varied from 2.9 to $4.8 \mathrm{t} / \mathrm{ha}$.
\end{abstract}

\section{KeY WORDS}

Northern Kazakhstan, Scots pine, chemical analyses, plantations

\section{INTRODUCTION}

According to Dixon et al. (1994), forests play a significant role in the global carbon cycle. According to different estimates by scientists, carbon stock in the world's forest ecosystems is 1100 billion tons, distributed over the zones of boreal, temperate and tropical forests in the ratio of 49,14 and $37 \%$ respectively. Also, forest systems absorb a huge amount of $\mathrm{CO}_{2}$ emitted into the atmosphere by various enterprises. According to the lat- 
est data, the land area belonging to the state forest fund of the Republic of Kazakhstan amounts to 29.3 million hectares or 10.7 percent of the republic's territory. Forest covered land occupies 12.6 million hectares or 43 percent of the total area of forest fund lands. The forest cover of the republic is 4.6 percent. Of these, about 1605.8 thousand hectares or $13 \%$ of the territory are coniferous.

However, according to some researchers, forests can not only absorb carbon dioxide but also isolate it, since besides photosynthesis there are many other processes in which carbon dioxide re-enters the atmosphere. Therefore, not every forest can sequestrate carbon, but if it consists of young and fast-growing plantations, then the net flow will be greater than the emission. Therefore, one of the important measures for reducing greenhouse effect is the creation of artificial green plantations in non-forest areas and forest lands, on which, due to a number of circumstances, there is no natural reforestation. Newly created forest cultures are actively involved in the processes of carbon dioxide binding and increasing the biological productivity of forest ecosystems. Carboniferous plantations should be created using forest plants with enhanced absorption of greenhouse gases. Scots pine could also be included in the category of coniferous tree species. According by Liu et. al. (2001), Parzych (2013) and Verma (2017), pine needles produce up to $1.3-2.0 \mathrm{~kg}$ of organic matter. Many studies on the deposition of carbon by pine plantations were conducted in Poland. For example, Oleksyn et al. (1999) analysed the distribution of aboveground biomass in the plantations of pine trees. The distribution of above-ground biomass in the age of up to 20 years was also estimated by Jagodziński et al. (2014, 2018). Socha and Wężyk (2004), as well as Zasada et al. (2008) studied the above-ground biomass of this tree species. From this point of view, it is of considerable interest to conduct studies on the carbon sequestration in the above-ground biomass of Pinus sylvestris L., the pine plantations in the green zone of the city of Astana, the first to be established in Central Asia.

In this regard, the purpose of our study was to determine the carbon content in the above-ground biomass and the possibility of carbon sequestration by plantations of Scots pine in the green belt of the city of Astana. To achieve this goal, the following tasks were set: measurement of the morphometric parameters of Scots pine; calculation of biomass values of plantations on the basis of regression equations; determination of the carbon content in different fractions of biomass by applying analytical methods; calculation of carbon content per 1 ha of plantations.

\section{Material AND methods}

The studies were carried out in the forest plantations of the green belt on the lands of LLP 'Astana Ormany' located in the south-western part of the city in 2016-2017. Green belt has a total area of 14,827 hectares, including 11,502.2 hectares of planted forests, which grow more than 9.6 million trees and about 1.9 million shrubs. It should be noted that of these, 13,826 hectares with a total, including 10,525 hectares with the actual area, are newly created by planting trees with forest belts while maintaining inter-coniferous spaces with plantations that do not exceed 14-16 years old. Which are mainly represented by deciduous and coniferous species: birch, elm, broad-leaved elm, pine, narrow-leaved elm, a poplar of Kazakhstan, golden currant, white drool, cherry Besseya, honeysuckle Tatar.

Astana has a sharply continental climate with arid summer and cold snowy winter. The average annual precipitation is $307 \mathrm{~mm}$. Geographical coordinates were measured with a Garmin eTrex 10 devices: $51.01920 \mathrm{~N}$, 071.36917 E. The objects of research was a Scots pine (Pinus sylvestris L.) plantation. Two-year seedlings of Scots pine were planted in 2000, which were grown in the breeding nursery and transported to the landing site in containers with the closed root system. To assess the condition of medium-growth plantations in the phase of individual growth in characteristic places, trial plots were laid with the expectation that there would be at least 200-250 trees of the main breed on it. The biomass of Scots pine was calculated on the basis of data on the height and diameter of the trunk at the breast level. The taxation indicators were calculated by methods commonly used in taxation: the taxation and average arithmetic; the height was calculated by spreading the height curve. The height and diameter of the tree trunks were measured with a laser instrument Masser and calipers SHID-05.

Trial areas were laid according to the recommendations of Usoltsev et al. (2005). Plots of plantations for laying trial plots were selected on the basis of analysis of for- 
est inventory materials and a route survey of the research area. Plantings were selected, homogeneous in the horizontal and vertical structure, according to the taxation indicators and conditions of the site of occurrence. The plantations were planted in the north-west direction. Trial areas for common pine were laid in triplicate (Fig. 1).
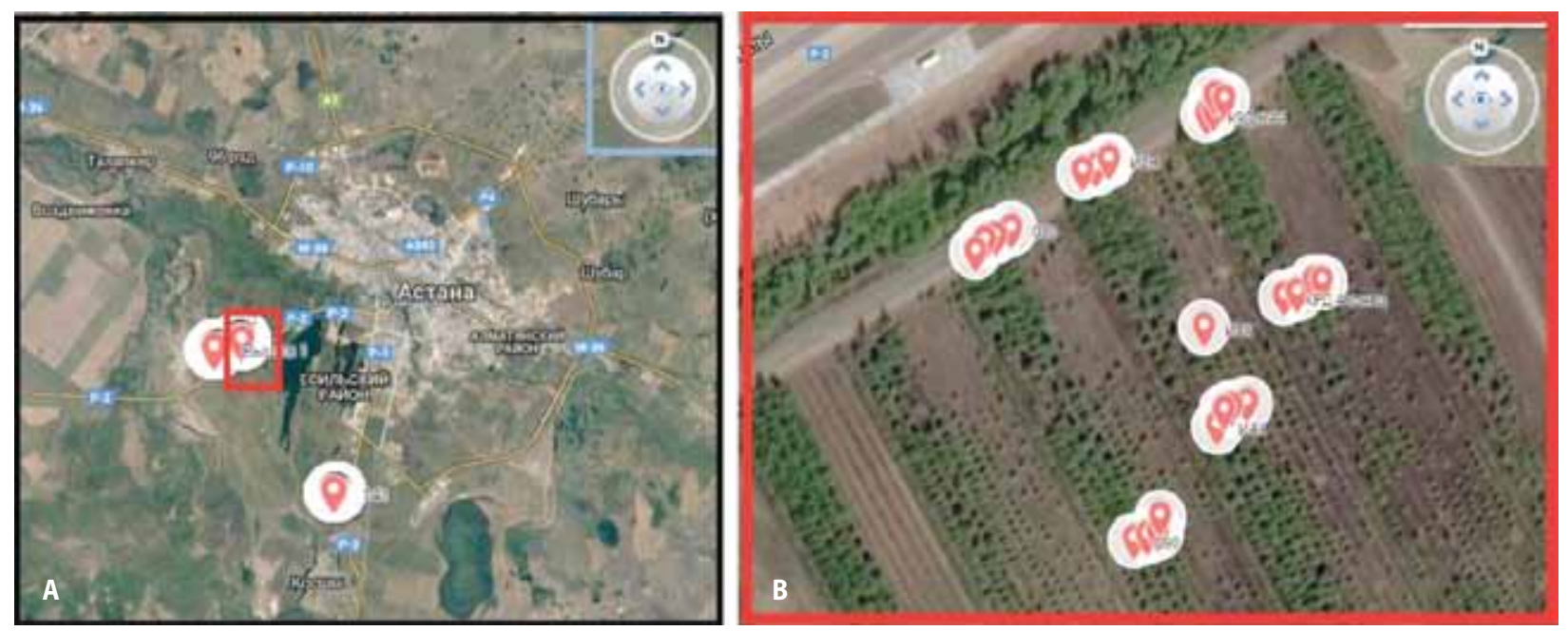

Figure 1. Trial areas laid in the green belt of Astana city $\mathrm{A}$ - general view of the location of trial plots, $\mathrm{B}-$ location in rows, 3 replicates

To estimate the pine biomass, regression equations were applied of Usoltsev (2016), which include, as independent variables, the diameter of the trunk and the height of the tree:

$$
\begin{aligned}
\ln P i= & \mathrm{a}_{\mathrm{o}}+\mathrm{a}_{1}(\ln H)+\mathrm{a}_{2}(\ln H)^{2}+\mathrm{a}_{3}(\ln D)+ \\
& +\mathrm{a}_{4}(\ln D)^{2}+\mathrm{a}_{5}(\ln D \cdot \ln H)+\Sigma\left(\mathrm{a}_{\mathrm{i}} \mathrm{X}_{\mathrm{i}}\right)
\end{aligned}
$$

were:

$\mathrm{Pi}$ - mass of the $i^{\text {th }}$ fraction of the tree in an absolutely dry state, $\mathrm{kg}$ (stem, branches, foliage or needles, aboveground and underground, respectively Pst, Pbr, Pf, Pa, Pr),

$\mathrm{H}$ - the height of the tree, $\mathrm{m}$,

$\mathrm{D}$ - diameter at the breast height, $\mathrm{cm}$.

The content of carbon in the samples was determined by selecting the elements of biomass for chemical analysis. Ten (10) samples were taken from each element of biomass (branches, trunk, leaves, and bark) of Scots pine in triplicate. After that, the green mass was weighed on analytical scales to within $0.001 \mathrm{~g}$. The samples were then dried to a constant weight at a temperature of $65^{\circ} \mathrm{C}$ in a drying cabinet.

After drying, a material weighing 2 grams was taken for chemical analysis. The material was ground, labelled and sent to a laboratory. In laboratory samples without mineralization, the content of carbon (C) was determined using the LECO TruMac CNS element analyser (LECO Corporation, Saint Joseph, Michigan, USA were performed in the Laboratory of Geochemistry of Forest Environment and Areas Designated for Reclamation, Department of Forest Ecology and Reclamation and Department of Forest Soil Science, Faculty of Forestry at the University of Agriculture in Krakow.

When determining the content of carbon in different parts of the biomass, it was revealed that the greatest amount of carbon (C) was $51.33 \%$ contained in the needle samples, and the lowest in the barrel samples was $46.89 \%$ (Tab. 1).

Table 1. Mean $( \pm$ SD) concentrations of carbon $(C)$ in different tree parts of sampled Scots pine stands, $\%$

\begin{tabular}{|c|c|c|c|c|c|}
\hline Trunk & Branches & Needles & Bark & LSD $_{05}$ & SD \\
\hline 46.89 & $\begin{array}{l}50.03+ \\
+3.135\end{array}$ & $\begin{array}{c}51.33+ \\
+4.447\end{array}$ & $\begin{array}{c}50.16+ \\
+3.27\end{array}$ & 0.3079 & $\begin{array}{c}0,1061 \\
0.1061\end{array}$ \\
\hline
\end{tabular}

Statistical analyses data processing was performed using the Statistical Package Excel, Statistika for correlation between the basic taxation. In this regard, Fig- 
ure 2 shows a linear correlation between the diameter at the breast level and the height of the planted pine.

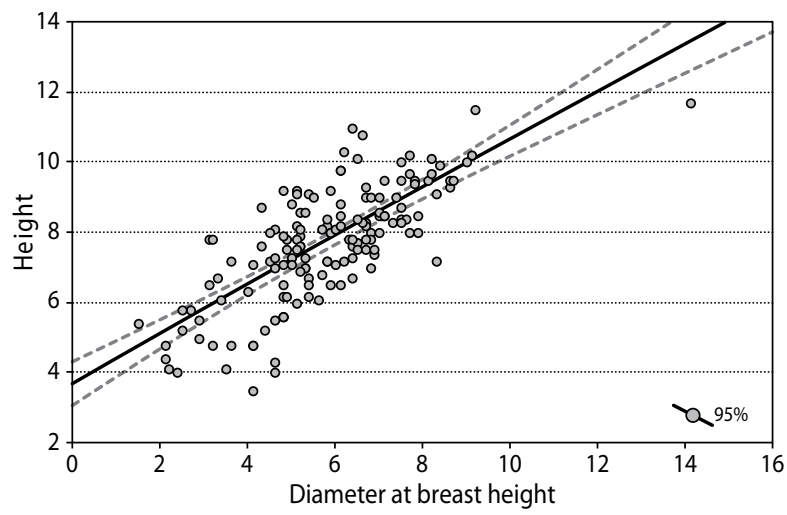

Figure 2. Correlation relationship of height and diameter at the breast height of stands of Scots pine

According to the materials received, we can say that there is a strong correlation between the morphometric parameters (height and diameter at the breast height). The correlation was 0.745 .

\section{Results}

During the years 2016-2017, the measurements of morphometric parameters for pines aged up to 17 years such as height and diameter at the breast height (DBH) were carried out (Tab. 2).

Table 2. Average height and diameter of pine stands

\begin{tabular}{|c|c|c|c|c|c|}
\hline № & $\begin{array}{c}\text { Area of trial plots } \\
\mathrm{m}^{2}\end{array}$ & $\begin{array}{c}\text { Age } \\
\text { years }\end{array}$ & $\begin{array}{c}\text { Height } \\
\mathrm{m}\end{array}$ & $\begin{array}{c}\text { DBH } \\
\mathrm{cm}\end{array}$ & $\begin{array}{c}\text { Biomass } \\
\text { t/ha }\end{array}$ \\
\hline 1 & 750 & 17 & 5.8 & 7.7 & 8.4 \\
\hline 2 & 750 & 17 & 8.1 & 8.6 & 13.6 \\
\hline 3 & 750 & 17 & 8.4 & 8.8 & 13.9 \\
\hline
\end{tabular}

As shown in Table 2, on average, the height of pine stands varied from $5.8 \mathrm{~m}$ to $8.4 \mathrm{~m}$. The diameter at the breast height (DBH) of pine was 7.7 to $8.8 \mathrm{~cm}$.

Our studies demonstrate that on average, the carbon content (C) was $50.3 \%$, in the branches, $46.89 \%$ in the barrel, $51.33 \%$, in the needle samples and $50.16 \%$ in the bark samples. Carbon sequestration in Scots pine biomass in different trial plots is shown in Figure 3.
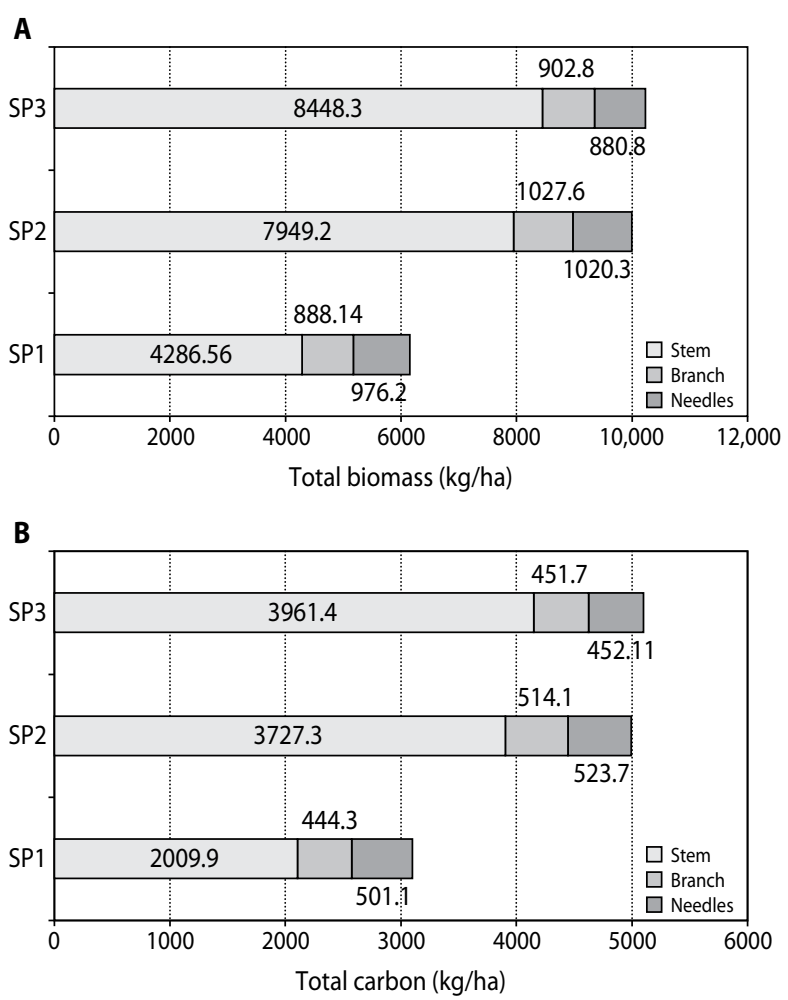

Figure 3. The content of carbon (C) in various elements of the biomass (trunk, branches, needles) of Scots pine by trial plots (SP1 - the first trial area, SP2 - the second trial area, SP3 - the third trial area), $\mathrm{kg} / \mathrm{ha}$; A - total biomass per hectare; $\mathrm{B}$ - total carbon per hectare

\section{Discussion}

According to Zianis et al. (2005), for many empirical models, diameter at breast height (D), height of trees (H) or both combinations are employed. The results of studies $\mathrm{He}$ et al. (2018), in the northeast of China showed that the largest distribution of biomass of all species in combination was in stems $(57.1 \%)$, followed by large roots $(21.3 \%)$, branches $(18.7 \%)$ and foliage (2.9\%). According to Gahagan et al. (2015), the greatest accumulation and storage of carbon occurs in dominant trees. According to Osipov (2017) the contribution of the stand to the total net productivity of the biomass of the blueberry pine is about $70 \%$.

Skonieczna et al. (2014) pointed out that the greatest concentration of $\mathrm{C}$ was observed in needles and the smallest in the trunk of trees. The relationship between the content of elements and the density 
of plantations or DBH was weak and in both cases negative.

According to Zhang et al. (2009), the mass fraction of carbon $(50 \%)$ in dry wood is used as a conversion factor for biomass in carbon stocks. In studies conducted on the pine in Northeast China, the carbon content varied from $47.1 \%$ at the roots to $51.4 \%$ in the foliage.

In the studies of Jagodziński et al. (2018) conducted in Western and Central Poland on the evaluation of young plantations, research was carried out using a complex set of allometric equations and coefficients of conversion of biomass (BCEF) based on the height and density of stands. As a result of the research, it was determined that the models based on height allow for a better estimate of the biomass of the stand and carbon deposition in the stands. Also, Jagiełło et al. (2017) conducted studies in Western Poland on theoretical discrete distributions in breast diameter modelling (DBH) and developed the most simplified model for use in many branches of forestry for a more accurate calculation of aboveground biomass.

Conclusion

Thus, according to the stated goal of the conducted studies to determine the carbon content in various elements of above-ground biomass and the possibility of carbon sequestration by plantations of Pinus sylvestris in the green belt of the city of Astana, it can be said that the 17-year-old pine plantations grow in sharply continental conditions of the dry steppe zone and average height from 5.8 to $8.4 \mathrm{~m}$ and diameter from 7.7 to $8.8 \mathrm{~cm}$, can accumulate in trunks from 2.1 to 3.9 tons, in branches from 0.44 to 0.51 tons and in needles from 0.45 to 0.52 tons of carbon on one hectare with the largest content of clover in the needles of a pine tree.

This work was supported by the Science Committee of the Ministry of Education and Science of the Republic of Kazakhstan within the framework of 217 budget program (project No. 4182 / GF4, number of the state registration 0215РК0264).

\section{References}

Dixon, R.K.K., Solomon, A.M.M., Brown, S.A., Houghton, R.A.A., Wisniewski, J. 1994. Carbon Pools and Flux of Global Forest Ecosystems. Science, 263, 5144.
Dmuchowski, W., Kurczynska, E.U., Wloch, W. 1998. Chemical Composition of Needles and Cambial Activity of Stems of Scots Pine Trees. USDA Forest Service Gen.Tech.Rep. PSW-GTR-166, 197-204.

Gahagan, A., Giardina, C.P., King, J.S., Binkley, D., Pregitzer, K.S., Burton, A.J. 2015. Carbon fluxes, storage, and harvest removals through 60years of stand development in red pine plantations and mixed hardwood stands in Northern Michigan, USA. Forest Ecology and Management, 337, 88-97.

He, H., Zhang, C., Zhao, X., Fousseni, F., Wang, J., Dai, H., Yang, S., Zuo, Q. 2018. Allometric biomass equations for 12 tree species in coniferous and broadleaved mixed forests Northeastern China. PLoS ONE, 13 (1), 1-16.

Jagiełł, R., Beker, C. 2017. Simplified model of diameter distribution for even-aged unthinned Scots pine (Pinus sylvestris L.) stands (in Polish with English summary). Sylwan, 161 (10), 822-830.

Jagodziński, A.M., Dyderski, M.K., Gęsikiewicz, K., Horodecki, P., Cysewska, A., Wierczyńska, S., Maciejczyk, K. 2018. How do tree stand parameters affect young Scots pine biomass? - Allometric equations and biomass conversion and expansion factors. Forest Ecology and Management, 409, 4-83.

Jagodziński, A.M., Kałucka, I., Horodecki, P., Oleksyn, J. 2014. Aboveground biomass allocation and accumulation in a chronosequence of young Pinus sylvestris stands growing on a lignite mine spoil heap. Dendrobiology, 72, 139-150. http://dx.doi. org/10.12657/denbio.072.012.

Liu, C.-J., Westman, C.J., Ilvesniemi, H. 2001. Matter and nutrient dynamics of pine (Pinus tabulaeformis) and oak (Quercus variabilis) litter in North China. Silva Fennica, 35 (1), 3-13.

Martin, J.G., Kloeppel, B.D., Schaefer, T.L., Kimbler, D.L., Steven, G., McNulty, S.G. 1998. Aboveground biomass and nitrogen allocation often deciduous southern Appalachian tree species. Canadian Journal of Forest Research, 28, 1648-1659.

Oleksyn, J., Reich, P.B., Chałupka, W., Tjoelker, M.G. 1999. Differential above- and below-ground biomass accumulation of European Pinus sylvestris populations in a 12- year-old provenance experiment. Scandinavian Journal of Forest Research, 14, 7-17. http://dx.doi.org/10.080/02827589908540804. 
Osipov, A.F. 2017. Reserves and flows of organic carbon in the ecosystem of a ripe pine bilberry blueberry taiga. Siberian Forest Journal, 2, 70-80.

Parzych, A., Sobisz, Z. 2012. The macro- and microelemental content of Pinus sylvestris L. and Pinus nigra J.F. Arn. needles in Cladonio-Pinetum habitat of the Słowiński National Park (in Polish with English summary). Leśne Prace Badawcze, 73 (4), 295-303.

Skonieczna J., Małek S., Polowy K., Węgiel A. 2014 Element content of Scots pine (Pinus sylvestris L.) stands of different densities. Drewno, 57 (192), 77-87.

Socha, J., Wężyk, P. 2004. Empirical formulae to assess the biomass of the above-ground part of pine trees. Electronic Journal of Polish Agricultural Universities, Forestry, 7. http://www. ejpau.media.pl/volume7/issue2/forestry/art-04.html.

Son, Y., Gower S.T., 1991. Aboveground nitrogen and phosphorus use by five plantation-grown trees with different leaf longevities. Biogeochemistry, 14: 167-197.

Usoltsev, V.A. 2016. Phytomass of model trees of forestforming rocks of Eurasia: data base, climatically conditioned geography, taxation standards: scientific edition (ed.: V.A. Usoltsev). The Ural State Forest Engineering University, Ekaterinburg, Russia.

Usoltsev, V.A., Zalesov, V.A. 2005. Methods for determining biological productivity. The Ural State Forest Engineering University, Ekaterinburg, Russia.

Verma, A., Mondal, P. 2017. Pyrolysis of pine needles: effects of process parameters on products yield and analysis of products. Journal of Thermal Analysis and Calorimetry. 10.1007/s10973-017-6727-0.

Zasada, M., Bronisz, K., Bijak, Sz., Wojtan, R., Tomusiak, R., Dudek, A., Michalak, K., Wróblewski, L. 2008. Empirical formulae for determination of the dry biomass of aboveground parts of the tree (in Polish with English summary). Sylwan, 152 (3), 27-39.

Zianis, D., Muukkonen, P., Mäkipää, R., Mencuccini, M. 2005. Biomass and stem volume equations for tree species in Europe. Silva Fennica Monographs, 4, 63.

Zhang, Q., Wang, C., Wang, X., Quan, X. 2009. Carbon concentration variability of 10 Chinese temperate tree species. Forest Ecology and Management, 258 (5), 722-727. 